\title{
聴性脳幹反応各波消失例の検討
}

\author{
八木 聰明*・加我 君孝**・馬場 俊吉*
}

\section{Partial Disappearance of the Waves in the Auditory Brain Stem Responses}

\author{
Toshiaki Yagi and Shunkichi Baba \\ (Nippon Med. School) \\ Kimitaka Kaga \\ (Teikyo Univ.)
}

The partial disappearance of the ABR waves was reported in the cases of twenty patients. Only wave I response was recorded in 18 ears tested. Waves I \& II, waves I, II \& III and waves I, II, III \& IV responses were observed in 4 ears, 8 ears and 5 ears, respectively. Cases included pontine glioma(8), acoustic tumor(4), West syndrome(2), leukodystrophy(2), facial neurinoma(1), epidermoid tumor(1), pontine bleeding(1) and unknown cause (1). Fourteen were cases of tumors. Thus if the ABR shows a partial wave disappearance, space occupying lesions in the brain stem should be suspected.

\section{は じめに}

聴性脳幹反応 (Auditory Brainstem Response, ABR) は，その起源が脳幹に由来するととか ら, 脳幹の神経学的検查法として, その発見直後から臨床応用され, Sohmer ら ${ }^{12)}$, Starr $~{ }^{13)}$, Stockard $ら^{16)}$ の先駆的報告がなされ，本邦であ加我ら ${ }^{4}$ の報告以来かなりの報告がみられるように なっている.

脳幹障害のときに現われる A B R の異常は 2 つ大別できる.すなわち, 潜時（各波間潜時, interwave latency) の延長と, 波の消失である ${ }^{18)}$ (図 1 ). 波の消失は, どの波から後が消失した かにより，4つに分類できる，つまり，(1) I波以降，(2III波以降，(3IV 波以降，(4)V 波以後，それ ぞれの消失である，もちろん，I波から全ての波が得られないものもあるが，乙れは無反応である ので分類から除いた.

現在まで，潜時の延長と，波の消失に関して数多くの報告がある。しかし，てれらは，種々の疾 患, たとえば, 聴神経腫瘍 (Selter $ら^{11)}$, Clemis $ら^{1)}$ ), 脳幹の腫瘍 (加我 ${ }^{5)}$, Yagi $ら^{20)}$ ), 多 発性硬化症 (Robinson $ら^{10)}$, Stockard $ら^{17)}$, Starr $ら^{13)}$, Mogensen $ら^{8)}$ ) , 他の変性疾患 (八 木ら $\left.{ }^{12)}\right)$ ，それに昏睡状態 (Starr ら ${ }^{1415)}$ ，Uziel ら ${ }^{19)}$ ) などのときに，ABRにどのような異常が

*日本医科大学耳鼻咽喹科学教室（主任：奥田稔教授)

**帝京大学医学部耳鼻咽喉科学教室（主任：鈴木淳一教授） 
現われるかといった報告であり，逆に，波の消失がある場合，たとえば，I波だけを示す症例には どのような疾患があるかと言った方向からの報告はなされていない，そてで今回，A B R 各波の消 失した症例のみを対象として検討を加えた。

対

帝京大学医学部付属病院耳鼻咽堠科にて, A B R 検査を行ない波の消失を認めた 17 症例, および，日本医科大学付属病院耳鼻咽喉科にて

\section{方}

検査は，電気的にシールドされた防首室内に て行った。被検査者には, 原則としてペントバ ルビタールカルシウムを内服させ，防音室内に 仰臥位とし，睡眠中に検査を施行した。電極は 前額部 (陽極)，検查側乳突部（陰極）とし, 反対側乳突部を接地した。検査音は, $3 \mathrm{KHz} 1$

\section{症 例 検 討}

1. I 波のみの症例

A B R I 波のみ，つまり I波以降の消失は， 18耳に認められた(図 2)。内わけは，聴神経腫 瘍 3 耳, 顔面神経鞘腫 1 耳, 小脳橋角部類上皮腫 1 耳, 橋グリオーム 8 耳, 点頭てんかん (West syndrome) 3 耳, 白質萎縮症 (Leukodystrophy） 1 耳，および，原因不明の脳幹障害 1 耳 であった. 18耳のうち13耳（73\%）が腫瘍例で あった。 I 波の潜時が正常值の標準偏差内に入 るあのは，12耳（67\%）であり， 6 耳がその範 囲をこえ延長していた。【波以降の消失がある にもかかわらず，I 波の潜時が $67 \%$ 亿正常であ るととは，蝸牛神経のクリックに対する周期性 が，かなり強いものであるととを示唆してい る. I 波だけの反応で，しかもその潜時が延長 しているものは，図 3 に示すように橋グリオー 厶 ( 1 例 2 耳), 聴神経腫瘍 ( 1 例 2 耳), 顔面 神経鞘腫（1 例 1 耳), 原因不明 ( 1 例 1 耳) で あった。

2. I ， I 波のみの症例

A B R III 波以降の消失は，4耳に認められた (図 4), 内わけは, 聴神経腫瘍 1 耳, 点頭てん
A B R 施行をし波の消失をみた 3 症例の計 20 症 例，35耳の反応を対象とした。

\section{法}

周期のクックを用い，1回の測定は，2000回加 算とし，原則として 2 回以上の記録を行なっ た。クリックは， $85 \mathrm{~dB}$ とし， T D H39イヤホ ーンを通し検査耳に与えた。非検査耳には，必 要に応じてマスキングノイズを与えた。

\section{A B R Abnormalities}

1 Latency (interwave) prolongation

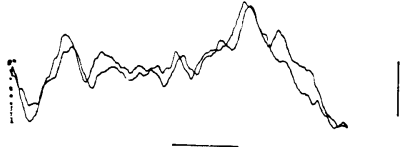

2 Wave Disappearance

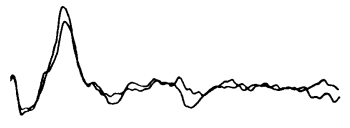

Normal

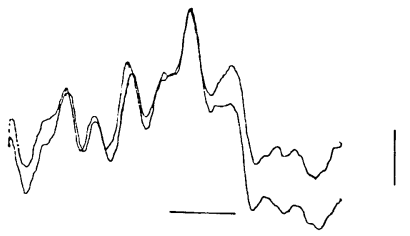

図 I 聴性脳幹反応（A B R）異常

1 . 潜時の延長 2 . 波の消失（例として II波以降 の消失）を示した.下に正常 A B R の例を示し た. 指標は, 横線 $2 \mathrm{msec}$, 縦線の $0.2 \mu \mathrm{V}$ で, 図 $2 ， 4 ， 5 ， 6$ のそれぞれの指標も全て同様 である。 


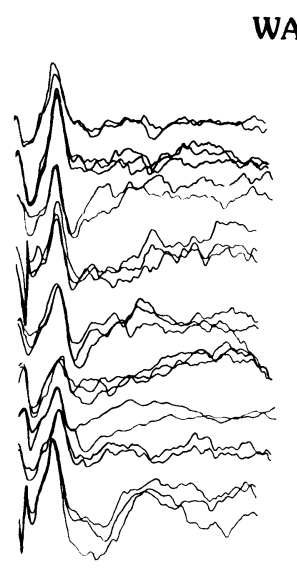

WAVE I

図2 A B R I 波のみを示した18耳の反応. 左列の 9 反応と右列上から 3 反応の指標は, 右列 3 番目 の反応のとてろに示し, 右列 4 番目からの反応 の指標は, 右列下に示した。

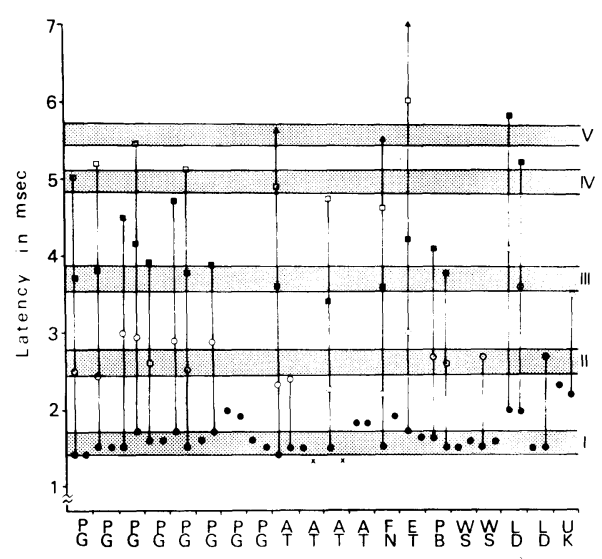

図 3 全症例の各波潜時.

$\mathrm{I} \sim \mathrm{V}$ 波の正常潜時の標準偏差の幅をうす塗り の領域で示した。黒丸は I 波, 白丸はII波, 黒 四角はIII波, 白四角はVI波, 黒三角はV 波の潜 時を示す. ×印は無反応を現わす. 1 例づつの 左の印は右耳の, 右の印は左耳の反応を示す.

P G：橋グリオーム, A T ：聴神経腫浣， F N : 顔面神経鞘腫, $\mathrm{E} T$ : 類上皮腫, $\mathrm{P} \mathrm{B}$ : 橋出 血, WS：点頭てんかん, LD：白質萎縮症, $\mathrm{UN}$ ：原因不明.

かん 1 耳, 白質萎縮症 1 耳, 原因不明 1 耳であ った，【波の潜時は，聴神経腫煬，点頭てんか ん, 白質萎縮症では正常範囲であったが，原因 不明例では著るしい延長を示している（図 3 ）. 3. I ， II， III 波の症例

\section{WAVE I II}

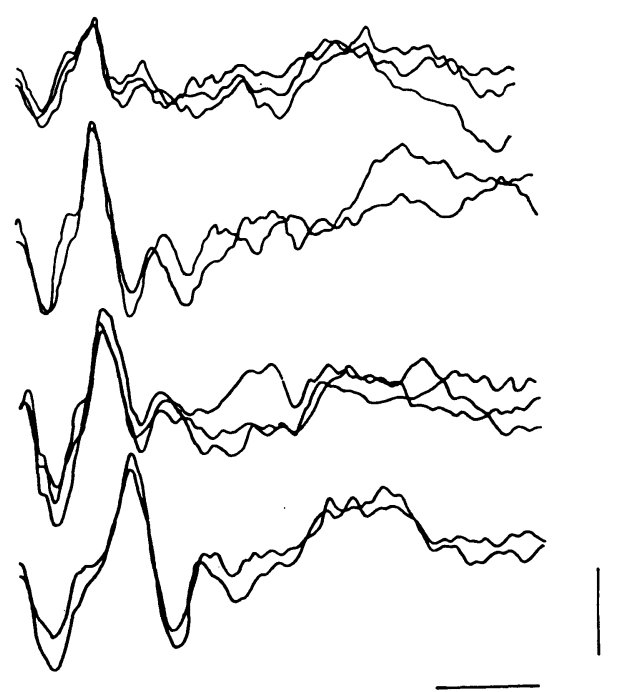

図 4 A B R I ， II 波のみを示した 4 耳の反応.

\section{WAVE I III}
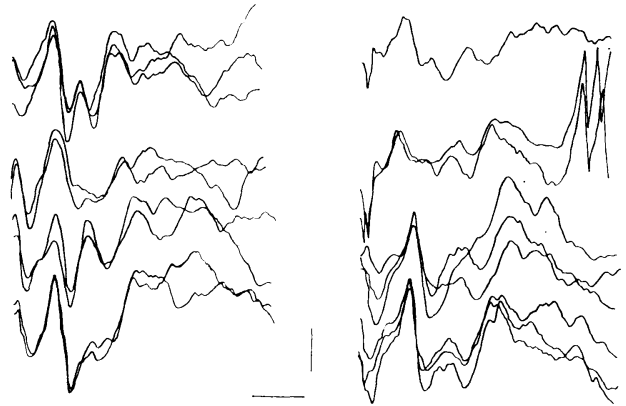

図 5 A B R I, II, III波を示した 8 耳の反応.

A B R IV 波以降の消失は，8耳に認められた (図 5 ). 内わけは, 橋グリオーム ( 4 耳), 橋 出血（ 2 耳), 白質萎縮症（ 2 耳）であった. 図 3 に示すように, III波の潜時は, 橋グリオーム のうち 3 例が延長, 白質萎縮症で著明な延長を 示し, 橋出乩では, 右耳は正常潜時, 左耳は延 長を示した。

4. I , II, III, IV 波の症例

A B R V 波の消失は，5耳に認められた（図 6 ). 内わけは, 橋グリオーム 4 耳, 聴神経腫 
WAVE I IV

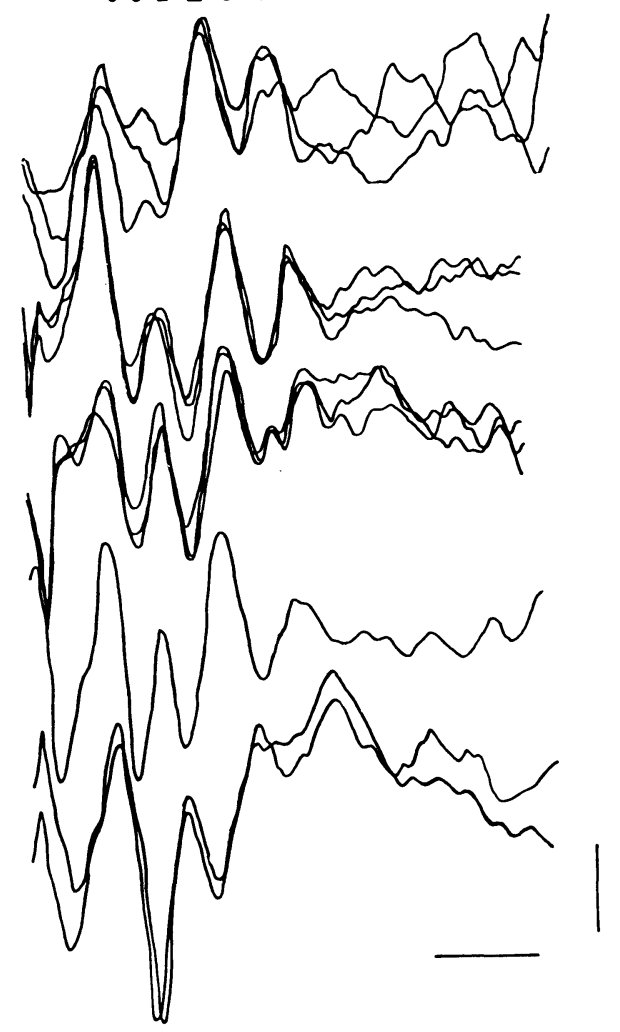

図 6 A B R I〜IV 波を示した 5 耳の反応.

瘍腫煬側 A B R は無反忍） 1 耳であった。III波 の潜時は，橋グリオーム 2 耳において延長，橋 グリオーム 2 耳と恥神経腫瘍では正常範囲であ った (図 3 ).

5. 全症例の検討

考

A B R 検査で，波の消失した 20 症例中14例 （70\%）が腫瘍例であった。これは，診断上， 波の消失をみた場合，まず病態として腫痬を考 えるべきであることを示している。しかし，乙 れも検査する施設でかなり異なるものと思われ る。たとえば，救急センタ一等で，意識消失の 症例を多く検査する場合は，脳幹出血などの血 管障害2 ${ }^{19}$ や, 中毒性（薬物中毒, 代謝性）脳 幹障钻 ${ }^{14)}$ をます念頭におく必要があろうし, 乳
表 I A B R 各波消失を示した 20 症例の疾患別症例数

\begin{tabular}{l|c}
\hline \multicolumn{1}{c|}{ 診 断 名 } & 症例数 \\
\hline 橋グリオーム & 8 \\
聴神経腫瘍 & 4 \\
点頭てんかん & 2 \\
白質萎縮症 & 2 \\
顔面神経鞘腫 & 1 \\
類上皮腫 & 1 \\
橋 出 血 & 1 \\
不 明 & 1 \\
\hline
\end{tabular}

A B R 各波の消失を示したものは20例35耳で あった２0例のうちわけは，表 1 に示すごと く, 橋グリオーム 8 例, 聴神経腫崲 4 例, 点頭 てんかん 2 例, 白質萎縮症 2 例, 顔面神経鞘腫 1 例, 小脳橋角部類上皮腫 1 例, 橋出血 1 例, 原因不明の脳幹障害 1 例である。このうち, 腫 瘍が14例（70\%）をしめ，A B R 各波の消失を きたすあのの多くが腫瘍であることを示してい る.

全例を通してみた潜時について, I 波潜時 は，26耳が正常，9耳（26\%）が延長，【波潜 時は，10耳が正常， 7 耳（41\%）が延長，III波 潜時は， 6 耳が正常， 7 耳が延長(54\%)，IV波 潜時は，3耳が正常， 2 耳 $(40 \%)$ が延長であ った，潜時の延長は，I波に比較的おこりにく く，I波以降におこりやすい傾向にあることを 示している.

察

幻児を多く検査する場合は, 腫瘍のほかに, 点 頭てんかん, 白質萎縮症などの, 広い意味での 変性疾患を忘れてはならないであろう。

橋グリオームが, 20例中 8 例に認められたて とは，腫瘍が䯣内で脳幹を冒すととから当然の ことと思われる。しかし, 病変の広がりによっ て，ABRのどの波から後が消失するかは異な っている，橋全体を冒すような広い病変では, Starr ら ${ }^{14)}$ 屯報告しているように，I波だけに 
なることもしばしばであり，本症例でも，2 例 に両側A B R がI 波で，しかも 1 例は，その潜 時む延長していた。一方, 広がりが圭右どちら かに偏在していたり，小さい場合には，1側の 反応が I 波だけ，他側が $\mathrm{I} 〜 \mathrm{IV}$ 波といった左右 異なる反応になるし，そのさい，しばしば】波 以降の波に潜時の延長が認められる。

聴神経腫瘍については, Selter ら ${ }^{11} の 35$ 例, Clemis ら" の27例の分析がある. Selterらは， 100\%に, Clemis らは，92.6\%にA B R V 波潜 時の延長と, 両耳反応間 $\mathrm{V}$ 波潜時差に異常を認 めているが, 各波消失については, 無反応以外 に記載がない.しかし, 聴神経腫瘍で I 波以外 の消失を認めている報告は数多くある ${ }^{315) 14) 227}$, 本報告では， 4 例の聴神経腫煬を示したが， 2 例はレックリングハウゼン病の両側聴神経腫瘍 例であり，1例は潜時の延長した I 波のみの反 応が両耳に認められ, 他の 1 例は， 1 側無反応 他側 I 波のみであり, 両側内耳道内での障害を 強く示唆している. 1 例は, 内耳道内に限局し た腫瘍であり，患側はI， I波のみだが反対側 には全く影響を与えておらず，同様に内耳道内 に限局した顔面神経鞘腫と似た所見を示してい る. 他の 1 例は, 患側無反応であるが, 腫瘍が
小脳橋佂部にあるため, 脳幹障害をおこし, 他 側の $V$ 波が消失している。このように，同じ聴 神経腫瘍であっても，腫瘍のできている場所， 大きさなどの違いで，ABRに異なった異常所 先を項わすことを示している。

点韻てんかん 2 例, 白質萎縮症 2 例に, A B $\mathrm{R}$ の波の消失が恐められた。加我ら ${ }^{6)}$ は, 点頭 てんかん後遺症21症例の検索を行ない，4例に 波の消失を認めている。内わけは，I波のみ 1 例， I ， I波のみ 2 例， I〜III波 2 例であった としており, 全身的発達とともに, 後の波が出 玩しだし，正常ABRになった例を示してい る.このととは, 乳児に执いては, たとえ異常 A B Rであっても, 発達の指標になるととを示 している。一方, 白質萎縮症について Ochs ら adrenoleukodystrophy の症例で, 病態の進行 につれて, 漸次, 後の波加ら消失するさまを報 告しており，ABR検査が病態の進行程度を知 る上で有用であることを示している. 本報告で 屯，1例はIV波まで，1例は，I波および I ， 【波の反応が認められ，これら屯病態の進行の， ある側面を示しているものと推測できる.

\section{おわりに}

A B R 各波消失を示した20症例を分析, 検徍した。20例中 14例が腫瘍であり，中でむ，橋グリオ 一ム (8 例), 恥神経腫瘍 ( 4 例) に, 波の消失をきたすむのの多いことを示していた。一方, 幼 小児では, 腫瘍だけでなく, 点頭てんかん（２例）, 白質萎縮症（２例）のような広い意味での変 性疾患があり，幼小児のA B R 検査で波の消失をみた場合，てれらの疾患屯念頭におく必要がある ことを述べた。

\section{文}

1) Clemis, J. D., McGee, T., : Brain stem electric response audiometry in the defferential diagnosis of acoustic tumors. Laryngoscope 89 : 31 42, 1979.

2) Gilroy, J., Lynn, G. E., Ristow, G. E., Pellerin, R. J., : Auditory evoked brain stem potentials in a case of "Locked-in" syndrome. Arch Neurol $34:$ 492 495, 1977.

\section{献}

3) House, J. W., Brackmann, D. E., : Brain stem audiometry in neurotologic diagnosis. Arch Otolaryngol $105: 305 \sim 309,1979$.

4 ) 加我君孝, 八木聡明, 花村哲 : Brainstem deafness 症例の Brainstem response. 耳鼻臨床 69 : 405 412, 1976.

5 ) 加我君孝, 高橋邦不, 八木聡明, 鈴木渖一：聴性 脳幹反応. 臨床検査 $21: 873 \sim 881,1977$. 
6 ) 加我君孝, 田中美郷：点頭てんかん症例の聴性行 動とその評価. Audiol Jap $22 ： 359 \sim 360,1979$.

7 ) Kaga, K., Tanaka, Y., Ushijma, H., Tokoro, Y., : The prognosis of adrenoleukodystrophy as revealed by auditory brain stem responses. Arch Otorhinolaryngol (submitted)

8 ) Mogensen, F., Kristnesen, O., : Auditory double click evoked potentials in multiple sclerosis. Acta neurol Scandinav $59: 96 \sim 107,1979$.

9 ) Ochs, S., Markand, O. N., DeMyer, W. E., : Brain stem auditory evoked responses in leukodystrophies. Neurol $29: 1089 \sim 1093,1979$.

10) Robinson, K., Rudge, P., : The stability of the auditory evoked potentials in normal man and patients with multiple sclerosis. J Neurol Sci $36: 147 \sim 156,1978$.

11) Selters, W. A., Brackmann, D. E., : Acoustic tumor detection with brain stem electric response audiometry. Arch Otolaryngol 103 : 181 187, 1977.

12) Sohmer, H., Feinmesser, M., Szabo, G., : Sources of electrocochleographic responses as studied in patients with brain demage. Electroenceph clin Neurophysiol $37: 663 \sim 669$, 1974.

13) Starr, A., Achor, L. K., : Auditory brain stem responses in neurological diagnosis. Arch Neurol $32: 761 \sim 768,1975$.

14) Starr, A., Hamilton, A. E., : Correlation between confirmed sites of neurological lesions and abnormalities of far-field auditory brainstem responses. Electroenceph clin Neurophysiol 4 I : 595 608, 1976.
15) Starr, A., : Auditory brain-stem responses in brain-stem responses in brain death. Brain $99: 543 \sim 544,1976$.

16) Stockard, J. J., Rossiter, V. S., : Clinical and pathologic correlates of brain stem auditory response abnormalities. Neurol $27: 316 \sim 325$, 1977.

17) Stockard, J. J., Stockard, J. E., : Shambaugh, F.W., : Detection and localization of occult lesions with brainstem auditory responses. Mayo Clin Proc $52: 761 \sim 679,1977$.

18）鈴木溥一，八木聡明：聴性脳幹誘発反応 Auditory brain stem evoked reponses (BSR, FFR) について. 帝京医誌 1：21〜30, 1978.

19) Uziel, A., Benezech, J., : Auditory brainstem responses in comatose patients ; Relationship with brainstem reflexes and levels of coma. Electroenceph clin Neurophysiol 45:515 $524,1978$.

20) Yagi, T., Kaga, K., : The effect of the click repetition rate on the latency of the auditory evoked brain stem responses and its clinical use for a neurological diagnosis. Arch Otorhinolaryngol $222: 91 \sim 96,1979$.

21）八木聡明, 加我君孝 : 変性疾患 6 症例の聴性脳幹 反応. 耳鼾臨床 $73: 139 \sim 144,1980$.

22）山田修, 加我君孝, 八木聡明, 神尾友和：内耳道 腫瘍の聴性脳幹反応. Equilibrium Res $37: 123$ 〜27, 1978 .

原稿到着：54年10月 25 日

別刷請求先：八木聡明

画113 東京都文京区干䭾木 $1-1-5$

日本医科大学耳鼻咽喉科学教室 